\title{
Loss of Ultraviolet Light Protection and Enhanced Ultraviolet Light-induced Mutability in Pseudomonas aeruginosa Carrying Mutant R Plasmids
}

\author{
By P. LEHRBACH, A. H. C. KUNG AND B. T. O. LEE \\ Department of Genetics, University of Melbourne, Parkville, Victoria 3052, Australia
}

(Received 6 January 1977; revised 22 February 1977)

\begin{abstract}
Two mutants of the R plasmid pMG2, selected on the basis of loss of enhanced ultraviolet light (u.v.)-induced mutability, no longer protected a wild type, a $u v r \mathrm{rec}^{+}$type mutant, or a polA type mutant of Pseudomonas aeruginosa against the lethal effects of u.v. For one of the R plasmid mutants tested, pPL2, a plasmid-determined DNA polymerase was no longer detected. The properties of these mutants support the hypothesis that a plasmid gene function responsible for enhanced u.v.-induced mutability also confers u.v.protection on the host cells. Furthermore a plasmid-determined DNA polymerase plays a major role in producing these effects.

On the basis of the effects of sodium arsenite on plasmid u.v.-protection and enhanced u.v.-induced mutability in strain TRPFI, it is proposed that a rec $A$-dependent, arsenitesensitive repair pathway is present in $P$. aeruginosa.
\end{abstract}

\section{INTRODUCTION}

Several R plasmids, including R-Utrecht (MacPhee, I973)and R46(Mortelmans \& Stocker, I976) in Salmonella typhimurium as well as pMG2 in Pseudomonas aeruginosa (Lehrbach et al., I977), have the ability to protect host cells against the lethal effects of ultraviolet irradiation while increasing the susceptibility of the host to the mutagenic effects of ultraviolet light (u.v.). These studies suggest that the plasmids carry a gene, or genes, which act to increase the extent of repair of u.v.-damaged host DNA. Furthermore, since an intact rec $A^{+}$gene is essential for these plasmids to exert their effect on the u.v. response of cells (MacPhee, 1973; Lehrbach et al., 1977), it is possible that the plasmid gene product(s) is involved in an error-prone repair pathway.

The pleiotropic effects of a recA mutation in S. typhimurium (MacPhee, I970), Escherichia coli (Clark \& Margulies, 1965) and $P$. aeruginosa (Chandler \& Krishnapillai, 1974) implicate this gene in the control of a number of different pathways. Repair inhibitors, such as chloramphenicol (Sedgwick, 1975), sodium arsenite (Rossman, Meyr \& Troll, 1975) and other chemicals (Smith, I97I), that inhibit a rec-dependent function have been used to separate and define various rec-dependent pathways. For example, the chloramphenicol-sensitive component of post-replication repair in $E$. coli apparently identifies an inducible errorprone mechanism (Sedgwick, I975). Sodium arsenite has been postulated to inhibit a pathway controlled by the rec $A$ gene, which involves the $\mathrm{exr}^{+}$gene and performs the majority of the recA-dependent repair in E. coli в (Rossman et al., I975).

The u.v.-protection function of the $\mathrm{R}$ plasmid $\mathrm{pMG}_{2}$ is dependent on a $\operatorname{rec} A$ gene (Lehrbach et al., 1977). Also, studies on cells deficient in a DNA polymerase I-type function in $P$. aeruginosa suggest that an $\mathrm{R}$ plasmid gene product of $\mathrm{pMG} 2$ may participate in the filling of single-strand gaps introduced during the repair of u.v.-damaged DNA. To investigate the extent to which an arsenite-sensitive repair pathway may be responsible for 
Table I. Bacterial strains

Strain no.

PAOI

TRPFI

GMBI I 2

GMA9I 8

PU2I(pMG2)

TRPFI(pPL2)

TRPFI(pPL3)
Strain characteristics*

prototrophic, $c h l-2$

trpFr

polA3

$u v r-8 T$

ilvBII2 leu-I str-I rif $\mathrm{FP}^{-} \mathrm{pMG} 2(\mathrm{Gm} \mathrm{Sm}$

Su Hg Phi E79 UV)

trpFI pPL2 (Gm Sm Su Hg Phi E79 $\left.\mathrm{UV}^{-}\right)$

trpFI pPL/3 (Gm Sm Su Hg Phi E79 UV-)
Reference

Holloway (1955)

Calhoun, Pierson \& Jensen (1973)

Lehrbach et al. (I976)

Kung \& Lee (1973)

Jacoby (1974)

This paper

This paper

* Antibiotic resistances: chl, chloramphenicol; rif, rifampin; Gm, gentamicin; Sm or str, streptomycin; $\mathrm{Su}$, sulphonamide. $\mathrm{Hg}$, Resistance to mercuric ions. Phi, Interference with phage propagation. UV, U.v. protection or resistance.

the observed u.v.-protection and enhanced u.v.-induced mutability of pMG2, we have tested the effects of sodium arsenite on the u.v.-survival and u.v.-induced mutability of strains carrying pMG2. Mutants of pMG2 were selected on the basis of enhanced u.v.-induced mutability. The properties of these mutants are described and a further definition of pathways involved in plasmid-mediated repair in $P$. aeruginosa is proposed.

\section{METHODS}

Bacteria. The standard wild-type strain is Pseudomonas aeruginosa PAOI (ATCCI 5692) (Holloway, 1955). Strains used in this study are listed in Table $\mathrm{I}$. R plasmid $\mathrm{pMG}_{2}$ is a P-2 group plasmid originally characterized by Jacoby (1974). R plasmid mutant derivatives of $\mathrm{pMG} 2$ have been named according to Novick et al. (1976).

General culture procedures, $N$-methyl-N'-nitro- $N$-nitrosoguanidine (NTG) mutagenesis, u.v.-irradiation and u.v.-survival curves. These techniques have been previously described (Kung \& Lee, 1973).

U.v.-mutagenesis. To determine the frequency of u.v.-induced mutations, the yield of $\operatorname{Trp}^{+}$back mutations of strain TRPFI following various u.v. doses was scored. Samples ( $0.1 \mathrm{ml})$ of irradiated and control cell suspensions were spread on minimal agar medium supplemented with $2.5 \%$ (v/v) nutrient broth (Oxoid, CM67). For each u.v. dose and for the spontaneous level, three plates were used. Survival following each u.v. dose was determined by plating on the same medium. Sodium arsenite was used at a final concentration of $\mathrm{I} \mathrm{mM}$.

Assay for DNA polymerase activity. The method used was that of Lehrbach, Kung \& Lee (I976).

$R$ plasmid transfer. Exponentially growing cultures of donor and recipient cells were mixed in a ratio of I: Io respectively in nutrient broth containing potassium nitrate at $4 \mathrm{mg} \mathrm{m}^{-1}$. The mixture was incubated for $2 \mathrm{~h}$ without shaking in a glass Petri plate at $37^{\circ} \mathrm{C}$. $\mathrm{R}^{+}$recipients were selected by appropriate genotype and drug resistance (sulphonamide resistance was not tested).

Isolation of R plasmid mutants. NTG-mutagenized clones of TRPFI (pMG2) were cultured in nutrient broth. Equal volumes of saline suspensions of these derivatives were then spotted on two broth-supplemented minimal medium agar plates. One plate was irradiated with $10 \mathrm{~J} \mathrm{~m}^{-2}$ and both plates were incubated for $48 \mathrm{~h}$ at $37^{\circ} \mathrm{C}$. Two of 750 clones tested were found to lack the enhanced u.v.-induced mutability associated with pMG2.

\section{RESULTS}

The two mutant $\mathrm{R}$ plasmids isolated in this study were selected by an on-the-plate test for loss of enhanced u.v.-induced mutability. They were designated pPL2 and pPL3 and retained resistance to gentamicin, streptomycin and mercuric ions as well as the ability to be transferred to various strains of $P$. aeruginosa. These mutant plasmids were tested for their ability to alter u.v.-survival in various genetic backgrounds and to enhance u.v.induced mutability in strain TRPFI. One of them, pPL2, was assayed for a plasmid-determined DNA polymerase I-type activity. 


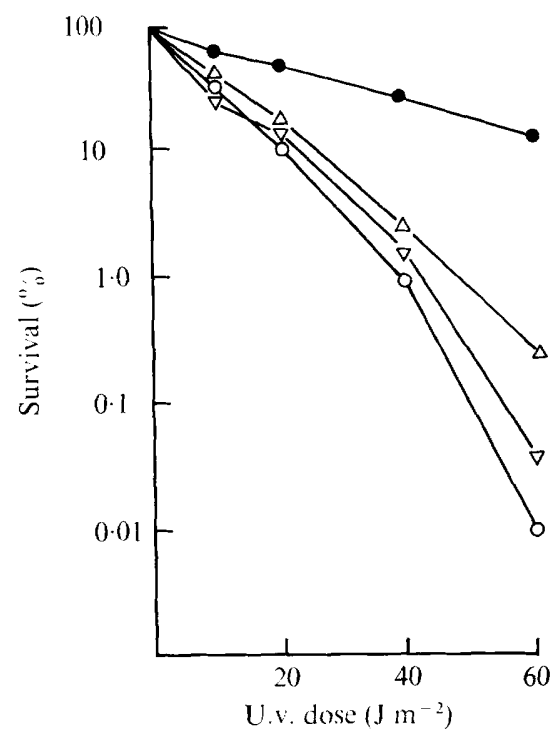

Fig. I. U.v.-survival curves of strain TRPFI $(O)$ containing R plasmid pMG2 and mutant R plasmids pPL2 $(\nabla)$ and $\mathrm{pPL}_{3}(\triangle)$.

Effect of the $R$ plasmid $\mathrm{pMG}_{2}$ and its derivatives $\mathrm{pPL}_{2}$ and $\mathrm{pPL}_{3}$ on u.v.-survival and u.v.-induced mutation in TRPFI

The plasmid pMG2 confers u.v.-protection to strain TRPFI. U.v.-survival curves of TRPFI containing pPL2 or pPL 3 did not show the extended shoulder associated with the u.v.-resistance of TRPFI(pMG2) (Fig. I). At higher u.v. doses a slight protective effect was observed for the mutant $\mathrm{R}$ plasmids in the TRPF I background which may indicate a slight residual plasmid repair function in these mutants.

Plasmid $\mathrm{pMG}_{2}$ substantially increased the mutation frequency after u.v.-irradiation whereas the mutant $\mathrm{R}$ plasmids $\mathrm{pPL} 2$ and $\mathrm{pPL}_{3}$ showed significantly lower u.v.-induced mutation frequencies in the TRPFI strain (Table 2). The spontaneous back mutation was similarly affected.

\section{Effect of $R$ plasmids $\mathrm{pMG} 2, \mathrm{pPL} 2$ and $\mathrm{pPL} 3$ on u.v.-survival in host-cell reactivation (hcr)- and polymerase (polA)-deficient mutants}

The presence of pMG2 protects the wild type and a variety of repair-deficient strains, including $h \mathrm{cr}$ and polA mutants of $P$. deruginosa, from u.v.-damage (Lehrbach et al., 1977). To determine whether bacteria containing pPL2 and PPL 3 had altered u.v.-sensitivity, these plasmids were transferred to a host-cell reactivation ( $h c r$ )- deficient strain GMA918 (Kung \& Lee, 1973) and to a polymerase (polA)-deficient strain GMBII2 (Lehrbach et al., 1976). U.v.-survival curves for these strains (Fig. $2 a, b$ ) showed that pPL2 and pPL3 have lost the ability to protect the $h \mathrm{cr}$ and polA strains against the lethal effects of u.v. A similar loss of u.v.-protection was shown for the wild-type strain (PAOI) from which the repair-deficient strains were derived (unpublished data).

\section{DNA polymerase activity associated with $\mathrm{pMG} 2$}

A plasmid-determined DNA polymerase I-type activity (i.e. assayable in crude sonicated extracts) has previously been studied in $P$. aeruginosa strain GMBI 2 carrying pMG2 (Lehrbach et al., 1977). To test if this polymerase function was concomitantly lost in the mutant 

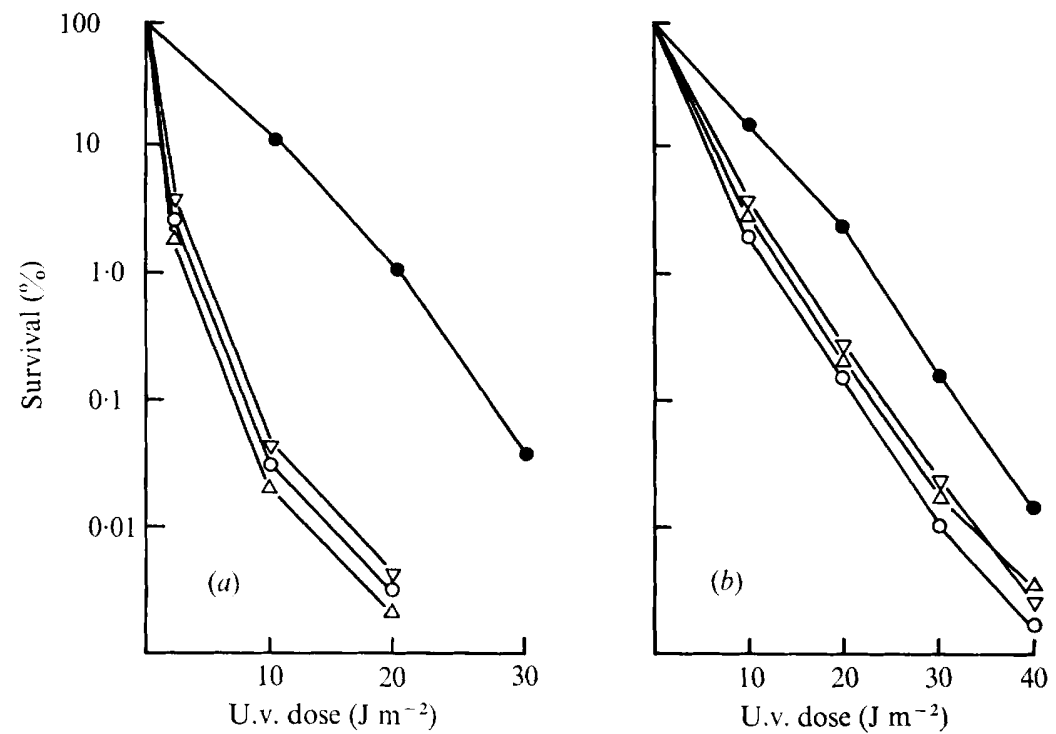

Fig. 2. U.v.-survival curves of strains (a) GMA9I 8 ( uvr-8I) and (b) GMBI 12 (polA3), with and without R plasmids: $O$, no plasmid; 0 , pMG2; $\nabla$, pPL2; $\triangle$, pPL 3 .

Table 2. U.v.-induction of Trp ${ }^{+}$revertants in strains TRPFI, TRPFI(pMG2), TRPFI(pPL2) and TRPFI(pPL3)

\begin{tabular}{|c|c|c|c|c|c|}
\hline \multirow[b]{2}{*}{ Strain } & \multirow[b]{2}{*}{ Medium* } & \multirow{2}{*}{$\begin{array}{l}\text { Spontaneous } \\
\text { frequency } \\
\text { per } 10^{7} \\
\text { cells }\end{array}$} & \multicolumn{3}{|c|}{$\begin{array}{c}\text { Induced frequency per } 10^{7} \text { survivors } \dagger \\
\text { at u.v. dose }\left(\mathrm{J} \mathrm{m}^{-2}\right) \text { : }\end{array}$} \\
\hline & & & 5 & 10 & 20 \\
\hline TRPFI & MB & 3 & $\begin{array}{l}8 \cdot 6 \\
(64)\end{array}$ & $\begin{array}{l}8 \cdot 4 \\
(31)\end{array}$ & $\begin{array}{l}36 \\
(8)\end{array}$ \\
\hline TRPFI(pMG2) & MB & 12 & $\begin{array}{l}240 \\
(90)\end{array}$ & $\begin{array}{l}392 \\
(73)\end{array}$ & $\begin{array}{l}526 \\
(6 I)\end{array}$ \\
\hline TRPFI(pPL2) & MB & 4 & $\begin{array}{c}23 \\
(85)\end{array}$ & $\begin{array}{c}33 \\
(43)\end{array}$ & $\begin{array}{l}48 \\
\text { (10) }\end{array}$ \\
\hline TRPFI (pPL3) & MB & 4 & $\begin{array}{l}27 \\
(79)\end{array}$ & $\begin{array}{c}56 \\
(43)\end{array}$ & $\begin{array}{l}94 \\
(9)\end{array}$ \\
\hline TRPFI & $\begin{array}{l}\text { MB }+ \\
\text { sodium arsenite }\end{array}$ & 0.8 & $\begin{array}{c}I \\
(80)\end{array}$ & $\begin{array}{l}3 \cdot 6 \\
(21)\end{array}$ & $\begin{array}{c}3 \\
(9)\end{array}$ \\
\hline TRPFI(pMG2) & $\begin{array}{l}\text { MB+ } \\
\text { sodium arsenite }\end{array}$ & $I \cdot 6$ & $\begin{array}{c}14 \\
(60)\end{array}$ & $\begin{array}{c}56 \\
(31)\end{array}$ & $\begin{array}{c}59 \\
\text { (10) }\end{array}$ \\
\hline
\end{tabular}

* MB, Minimal medium supplemented with $2.5 \%(\mathrm{v} / \mathrm{v})$ nutrient broth. Sodium arsenite was used at a final concentration of I mM.

$\dagger$ Numbers show the mean frequency of $\operatorname{Trp}^{+}$revertants per $10^{7}$ survivors, corrected for spontaneous mutations by subtracting the mean frequency of revertants on the non-irradiated plates (see Methods); numbers in parentheses show the percentage survival.

$\mathrm{R}$ plasmids (pPL2 and pPL3) which were selected on the basis of loss of enhanced u.v.-mutability, DNA polymerase activity was determined in a polA mutant (GMBII2) harbouring one of the mutant plasmids pPL2 (Fig. 3). Crude extracts of GMBI I 2 showed no detectable polymerizing activity whereas GMBI I2(pMG2) showed a significant increase in polymerase activity. This increase was not observed for GMBI I2(pPL2). 


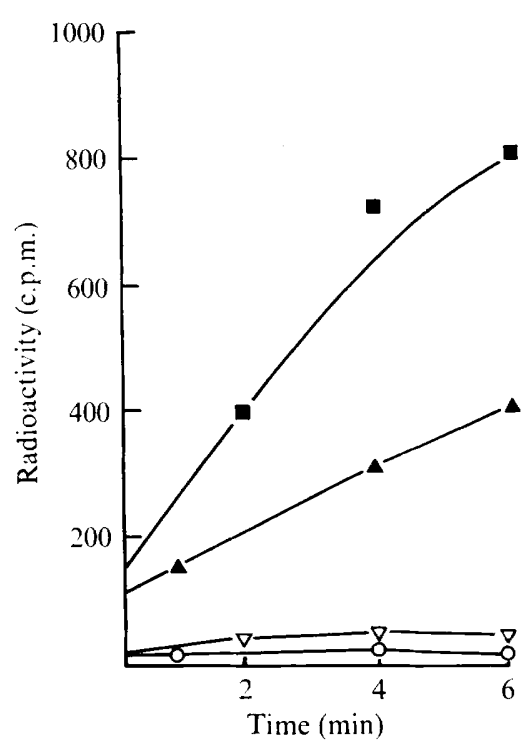

Fig. 3

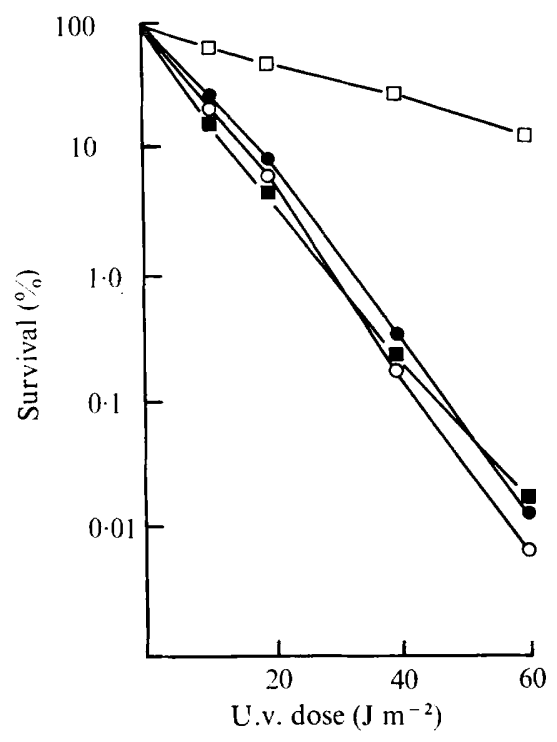

Fig. 4

Fig. 3. Assay of polymerase activity of strains: $\mathbf{0}$, PAOI; O, GMBII2; $\Delta$, GMBII2(pMG2); $\nabla$, GMB I I2(pPL2).

Fig. 4. U.v.-survival curves of strains TRPFI $(O, 0)$ and $\operatorname{TRPFI}(\mathrm{pMG})(\square, \square)$ in the presence $(\square, \square)$ or absence $(\bigcirc, \square)$ of I mM-sodium arsenite.

\section{Effect of sodium arsenite on $u . v .-$ protection and enhanced u.v.-induced mutability of $\mathrm{pMG} 2$}

Studies using $E$. coli B have shown that sodium arsenite inhibits a $r e c A$-dependent step in the repair of u.v.-irradiated DNA (Rossman et al., 1975). The arsenite-sensitive step contributes to the survival of cells following u.v.-irradiation because u.v.-irradiated $E$. coli (WP2) is more sensitive to u.v. when post-treated with sodium arsenite, whereas arsenite has no effect on the u.v.-survival of recA mutants (Rossman et al., 1975).

Since the u.v.-protective effect of $\mathrm{pMG}_{2}$ is dependent on the rec $A$ gene in $P$. aeruginosa the effect of a sublethal concentration of sodium arsenite (I $\mathrm{mM}$ ) in the plating medium following u.v.-irradiation was examined in strain TRPF I (wild type for repair) (Table 2, Fig. 4). The presence of sodium arsenite eliminated the extended shoulder of the u.v.-survival curve of TRPFI(pMG2) reducing the u.v.-survival of TRPFI(pMG2) to that of u.v.-irradiated strain TRPFI in the presence of sodium arsenite. U.v.-induced mutability of TRPFI(pMG2) was also significantly reduced.

\section{DISCUSSION}

The properties of the mutant R plasmids pPL2 and pPL3 which were selected on the basis of the loss of enhanced u.v.-mutability can be summarized as follows: (i) a significant reduction of u.v.-induced back mutation frequencies in TRPFI(PPL2) and TRPFI(PPL3) compared with TRPFI(pMG2); (ii) loss of enhanced spontaneous mutability in TRPFI(pPL2) and TRPFI(pPL3) compared with TRPFI(pMG2); (iii) loss of u.v.-protection in wild-type (TRPFI), polA (GMBI I2) and her (GMA9I8) host cells compared with the same strains carrying the R plasmid pMG2; (iv) loss of a plasmid-determined DNA polymerase I-type activity (tested only for mutant R plasmid pPL2).

These properties support the hypothesis that a plasmid gene function responsible for enhanced u.v.-induced mutability also confers u.v.-protection on the host cell containing pMG2, 
The slight protective effect of pPL2 and pPL3 observed at higher u.v. doses in TRPF I (Fig. I) and the increased levels of u.v.-induced back mutation (Trp $\left.{ }^{+}\right)$of TRPF (pPL2) and TRPFI(pPL3) (Table 2) could indicate the presence of further plasmid-mediated repair functions. It has been postulated that u.v.-protection produced by the R plasmid R46 in $E$. coli involves an inducible gene product which is possibly a nuclease and is dependent on a functional host recA gene for expression (Tweats $e t$ al., 1976). The presence of such an enzyme associated with pMG2 has not been examined, but such repair nucleases could play a part in plasmid-mediated u.v.-resistance in $P$. aeruginosa. However, on the basis of the properties of $\mathrm{R}$ plasmid mutant pPL2, the presence of a plasmid-determined DNA polymerase activity clearly plays a major role in altering the u.v.-survival and u.v.-induced mutability of bacteria carrying pMG2. It is possible that this plasmid-determined gene product may participate in the recA-dependent error-prone repair of u.v.-damaged host DNA in $P$. aeruginosa.

Both u.v.-survival and u.v.-induced mutability of TRPFI(pMG2) are greatly reduced in the presence of sublethal concentrations of sodium arsenite (I mM). These results suggest that the increased u.v.-repair capacity of bacteria carrying $\mathrm{pMG}_{2}$ is due to a $\operatorname{rec} A$-dependent, arsenite-sensitive step in DNA repair.

The association of repair genes as part of an $\mathrm{R}$ plasmid genome may have been in response to several agents which act to create structural modifications to DNA which resemble stages in the repair of u.v.- or $\gamma$-irradiated DNA (i.e. DNA strand breaks). The ability of antibiotics such as nalidixic acid (Gudas \& Pardee, 1976), bleomycin (Kuo \& Haidle, 1974) and phleomycin (Nakayama, 1975) to inhibit DNA synthesis and stimulate DNA degradation to produce DNA strand gaps is analogous to DNA strand breaks produced after excision of u.v.-induced pyrimidine dimers or breaks produced by $\gamma$-irradiation or treatment with methyl methanesulphonate or NTG. Strains of $P$. aeruginosa carrying the plasmid pMG2 are protected against the lethal effects of u.v- and $\gamma$-irradiation, methyl methanesulphonate and NTG.

This work was supported by a Research and Training grant from the Australian Institute of Nuclear Science and Engineering. We would like to thank Dr F. P. Imray for her comments during the preparation of the manuscript.

\section{REFERENCES}

Calhoun, D. H., Pierson, D. L. \& Jensen, R. A. (I973). The regulation of tryptophan biosynthesis in Pseudomonas aeruginosa. Molecular and General Genetics 121, $117-132$.

Chandler, P. M. \& Krishnapillai, V. (1974). Isolation and properties of recombination-deficient mutants of Pseudomonas aeruginosa. Mutation Research 23, 15-23.

Clark, A. J. \& Margulies, A. D. (1965). Isolation and characterisation of recombination deficient mutants of Escherichia coli K-I2. Proceedings of the National Academy of Sciences of the United States of America 53, 415-459.

Gudas, L. J. \& PARDEe, A. B. (1976). DNA synthesis inhibition and the induction of protein $\mathrm{X}$ in Escherichia coli. Journal of Molecular Biology ror, $459-477$.

Holloway, B. M. (I955). Genetic recombination in Pseudomonas aeruginosa. Journal of General Microbiology 13, 572-58I.

JACOBY, G. A. (1974). Property of R plasmids determining gentamicin resistance by acetylation in Pseudomonas aeruginosa. Antimicrobial Agents and Chemotherapy 6, 239-252.

Kung, A. H. C. \& LeE, B. T. O. (I973). The isola- tion and characterization of radiation and chemical-mutagen sensitive mutants of Pseudomonas aeruginosa. Mutation Research 20, 175-190.

Kuo, M. T. \& HAIDLE, C. W. (I974). Characterization of chain breakage in DNA induced by bleomycin. Biochimica et biophysica acta 335, 109I14.

Lehrbach, P. R., Kung, A. H. C. \& Lee, B. T. O. (1976). Mutants of Pseudomonas aeruginosa deficient in DNA polymerase I. Mutation Research 4I, 39I-394.

Lehrbach, P. R., KunG, A. H. C., Lee, B. T. O. \& JACOBY, G. A. (1977). Plasmid modification of radiation and chemical-mutagen sensitivity in Pseudomonas aeruginosa. Journal of General Microbiology 98, 167-176.

MacPhee, D. G. (I970). Recombination-deficient mutants of colicinogenic Salmonella typhimurium detected by their failure to release colicin. Journal of Bacteriology I04, 345-350.

MACPhee, D. G. (I973). Effect of rec mutants on the ultraviolet protecting and mutagen enhancing properties of plasmid R-Utrecht in Salmonella typhimurium. Mutation Research 19, 357-359. 
Mortelmans, K. E. \& Stocker, B. A. D. (1976). Ultraviolet light protection enhancement of ultraviolet light mutagenesis and mutator effect of plasmid R46 in Salmonella typhimurium. Journal of Bacteriology 128, 271-282.

NAKAYAMA, H. (1975). Phleomycin-induced lethality and DNA degradation in Escherichia coli K-I 2. Mutation Research 29, 2 I-33.

Novick, P. R., Clowes, R. C., Cohen, S. N., Curtiss III, R., DatTa, N. \& Falkow, S. (1976). Uniform nomenclature for bacterial plasmids: a proposal. Bacteriological Reviews 40, I68-189.

Rossman, T., Meyr, M. S. \& Troll, W. (I975). Effect of sodium arsenite on the survival of UVirradiated $E$. coli: inhibition of a $\operatorname{rec} A$-dependent function. Mutation Research 30, I 57-162.
SedGwick, S. G. (1975). Inducible error-prone repair in Escherichia coli. Proceedings of the National Academy of Sciences of the United States of America 72, 2753-2757.

SMITH, K. C. (I97I). The roles of genetic recombination and DNA polymerase in the repair of damaged DNA. In Photophysiology, vol. 6, pp. 209-278. Edited by A. C. Giese. New York: Academic Press.

Tweats, D. J., Thompson, M. J., Pinney, R. \& SмIтH, J. T. (I976). R factor-mediated resistance to ultraviolet light in strains of Escherichia coli deficient in known repair function. Journal of General Microbiology 93, 103-I 10. 